\title{
Women Involvement in Rural Community Development in Enugu North Senatorial Zone of Enugu State, Nigeria
}

\author{
Clement Okechukwu Attamah ${ }^{1}$, Anthonia Ngozi Asadu ${ }^{1}$, Chukwubuikem Chinenye Eze ${ }^{1}$ \\ ${ }^{1}$ University of Nigeria, Nsukka \\ Nsukka Road, 410001, Nsukka, Enugu State, Nigeria
}

DOI: $10.22178 /$ pos.55-4

LCC Subject Category: R51

Received 22.01.2020

Accepted 25.02.2020

Published online 29.02.2020

Corresponding Author:

Clement Okechukwu Attamah

clement.attamah@unn.edu.ng

\begin{abstract}
The study ascertained the involvement of women in rural community development (RCD). The study was carried out in Enugu north senatorial zone, Enugu State, Nigeria, with a total of 4 communities randomly selected from 2 randomly selected LGAs. The total sample size of 60 women was used. Data were collected using an interview schedule and analysed using percentages and mean scores. The findings reveal that agricultural related projects $(96.7 \%)$, social projects $(91.7 \%)$, educational projects $(81.7 \%)$ and health projects $(81.7 \%)$ were areas of RCD women were involved in. The agricultural related projects of interest included: animal rearing and sales $(96.7 \%)$, corn processing outfits $(91.7 \%)$, seasonal crop processing and production $(90 \%)$ among others. Traders association $(\bar{x}=2.45)$ and market women association $(\bar{x}=2.45)$ were RCD groups women were mostly part of, while women empowerment programs $(M=2.45)$, education $(M=2.42)$, urbanization $(M=2.42)$ among others were the factors that enabled women involvement in RCD. Women were involved and played a crucial role in RCD. A more conducive environment such as the provision of soft loans and jobs should be created by government authorities to sustain women's motivation and encourage them to delve into other areas of RCD like Information and Communication Technologies that their presence is not so pronounced.
\end{abstract}

Keywords: Educational projects; health project; social projects.

\section{INTRODUCTION}

The rural community has contributed more than $50 \%$ of global poverty reduction and plays a key role in agricultural advancement in many developing countries [4]. They are custodians of a large segment of the world's natural resources; contribute to global food security, economic growth, amongst others. In the developing world, the population of rural people is far much greater than that of the urban. About 694 million Africans or $59.6 \%$ and 95 million or $52.2 \%$ Nigerians live and derive their livelihood from the rural areas [14]. Rural communities serve as the country's major market for domestic production because residents of the rural areas engage in primary activities that form the foundation for any economic development [16].

Despite the importance of the rural community, there is a lack of social, physical and institutional infrastructure like quality education, health facilities, potable water, electricity, transportation, etc. [7]. The foregoing has made life difficult for many people living in these rural areas and is also a clear indication that there is a need for development.

According to [11], Rural Community Development (RCD) involves the transformation of the rural community into a socially, economically, politically, orderly and materially desirable condition to improve the quality of life of the rural population on a self-sustaining basis. It operates with four major principles which include; emphasis on community self-help, attention to communities felt needs, development of the community as an integrated whole and technical assistance [11]. Concepts of RCD in third world nations have been a serious issue for debate in the last decade. It has been the preoccupation of academicians, policymakers, practitioners, local, international communities, governments, and non-governmental organizations [15].

Rural community development gained prominence in developing countries like Nigeria during the colonial era when the social welfare officers 
promoted self-help to improve health, nutrition and general community welfare [12]. The federal, state and local governments are some of the principal actors in the establishment of these self-help rural community development programs and projects. For instance, [18] state that the efforts of the federal and state governments in Nigeria to improve the living conditions of the rural people, at various times encouraged the formation of co-operative movements by rural women farmers, craftsmen and women. According to the authors, the government established development centers in all the local governments in the country to realize the goal of the development of rural areas. Some of the many projects of the RCD programs include; Directorate of Food, Roads and Rural infrastructure (DFRRI), small and medium enterprises (SME) credit schemes, Family Economic Advancement Programs (FEAP), National Directorate for Employment (NDE) and Better Life for rural women programs amongst others. One of the major aims of rural communities in developing nations is to attain basic amenities such as roads, health centers, school buildings, good market centers, and community facilities. These amenities are important for meaningful agricultural production and a better standard of living.

But despite the many and different roles, approaches that the government and nongovernmental organizations have employed, the problems of rural development continue to visibly exist [5]. It has become very apparent that the government cannot satisfy the demands of the rural families and community as a whole, hence the visible lack of amenities needed for comfortable community living. Women and the female members of the rural communities have increasingly embarked on participating in many selfhelp development community projects. Women have become more enlightened and no longer wait on the government for support. Also, with the advancement in education, women have become wiser, bolder and actively and passionately involved in saving, sustaining and developing the rural communities through so many important community development programs and projects. The numerous roles women now play in community development have become more significant, pronounced and important and rural communities can no longer do without their input. For instance, during the colonial days and after the independence various communities through the women's contributions and involvement mainly financed some development projects such as the construction of roads, bridges, health centers, primary and secondary schools. Women also awarded scholarships to train their sons and daughters in higher education in Nigeria and abroad [13]. Women have also been found to engage in development projects like construction of footpaths, homesteads, clearing of farmlands, roads, group farming, sweeping of community market places especially on market days, maintenance of the king's palace, rotational farming, weeding of community footpaths and provision of other social infrastructural facilities required by the people.

Now, due to advancement in education, urbanization, globalization, and migration, women are delving into new roles and been involved more in RCD, coupled with the fact that Igbo-Eze north senatorial zone is an agrarian zone with so many rural communities, it then becomes so imperative to look at the roles performed by rural women about RCD. What are the RCD projects women do? And what are the factors that enable their involvement?

\section{METHODOLOGY}

The study was carried out in the Enugu North senatorial zone of Enugu State, Nigeria. The zone houses two of the six agricultural zones in Enugu State. Enugu north senatorial zone comprises of six local government areas, which are: Nsukka, Udenu, Uzo-Uwani, Igbo-Etiti, Igbo-Eze south, and Igbo-Eze north. The zone is a known agrarian area in the state with numerous rural communities. The population of the study comprised females (from the ages of 20 to 70years) who participate in self-help rural community development projects, hence the small size. Two LGAs were randomly selected from where two rural communities were selected, giving a total of four communities. Fifteen respondents were selected randomly from each community giving a total sample size of 60 respondents.

To ascertain the involvement of women in RCD, respondents were requested to indicate $R C D$ projects embarked on in their communities, which included; the building of primary and secondary schools, award of scholarships to indigenes, the building of cottage hospitals, building houses for widows, among others. The rural community development groups that women were involved in were ascertained by using a 
five-point Likert-type scale of very active (4), active (3), moderately active (2), slightly active (1) and not involved (0). The scores were added together and divided by five to get a mean score of 2. Hence, any score that is equal to or above the mean shows high involvement while scores below the mean indicate low involvement. Enabling factors that influenced women's involvement in RCD was determined by listing possible factors such as education, urbanization, women empowerment, globalization, migration, etc. A four-point Likert-type scale of high (3), moderate (2), low (1) and not at all (0) was used. These figures were summed and divided by 4 , to obtain a mean of 1.5. Therefore, any factor with a mean of 1.5 and above was regarded as an enabling factor, while that with a mean of less than 1.5 was dropped. Descriptive statistics and mean score were used in data analysis

\section{RESULTS AND DISCUSSION}

Personal characteristics of respondents. Data in Table 1 reveal that the mean age of the respondents was 40 years. The Table also shows that the majority $(66.7 \%)$ of the women were married with an average household size of 5 persons. About $62.0 \%$ were secondary school certificate holders, who were mainly (55\%) into trading as a major occupation and had N11, 000 as average monthly income. This implies that women in the area are predominantly in their middle ages, energetic, responsible, literate and income earners. And these are indicators that can give rural community development expression in a place.

Educational RCD projects. Table 2 shows that women were involved in the provision of educational facilities in the following areas: award of scholarships to indigenes (81.7\%), the establishment of lesson centers (71.7\%), building of primary schools (61.7\%), and building of secondary schools (8.3\%). This implies that the women work together to develop their communities educationally and also show that they appreciate the importance of education in community development. According to [1], education affects people's perception of new ideas, and RCD is not an exception.

Health RCD projects. Data in Table 2 show that the majority $(81.7 \%)$ of the respondents participated in health projects by building cottage hospitals.
Table 1 - Personal characteristics of the respondents

\begin{tabular}{|c|c|c|}
\hline Characteristics & Percentage $(n=60)$ & $\begin{array}{l}\text { Mean } \\
(\bar{x}) \bar{x})\end{array}$ \\
\hline \multicolumn{3}{|l|}{ Age (years) } \\
\hline$<20$ & 3.3 & \\
\hline 20-29 & 11.7 & \\
\hline $30-39$ & 15.0 & \\
\hline $40-49$ & 51.7 & 40 \\
\hline $50-59$ & 6.7 & \\
\hline 60 and above & 11.6 & \\
\hline \multicolumn{3}{|l|}{ Marital status } \\
\hline Single & 31.7 & \\
\hline Married & 66.7 & \\
\hline Widowed & 1.6 & \\
\hline \multicolumn{3}{|l|}{\begin{tabular}{|l|} 
Educational status \\
\end{tabular}} \\
\hline Primary education & 21.7 & \\
\hline Secondary education & 61.7 & \\
\hline Tertiary & 16.6 & \\
\hline \multicolumn{3}{|l|}{\begin{tabular}{|l|} 
Household size \\
\end{tabular}} \\
\hline $1-3$ & 10.0 & \\
\hline $4-6$ & 55.0 & 5 \\
\hline $7-9$ & 33.3 & \\
\hline Above 9 & 1.7 & \\
\hline \multicolumn{3}{|l|}{\begin{tabular}{|l|} 
Primary occupation \\
\end{tabular}} \\
\hline Artisan & 5.0 & \\
\hline Tailoring & 3.3 & \\
\hline Civil servant & 5.0 & \\
\hline Fishing & 1.7 & \\
\hline Farming & 1.7 & \\
\hline Student & 28.3 & \\
\hline Trading & 55.0 & \\
\hline \multicolumn{3}{|l|}{\begin{tabular}{|l} 
Monthly income (N) \\
\end{tabular}} \\
\hline$<3000$ & 6.7 & \\
\hline $3000-7000$ & 28.3 & \\
\hline $7000-11000$ & 5.0 & \\
\hline $11000-15000$ & 26.7 & 11000 \\
\hline $15000-19000$ & 18.3 & \\
\hline $19000-23000$ & 15.0 & \\
\hline
\end{tabular}

Seventy percent were involved in providing midwifery skills-acquisition centers, $65.0 \%$ provided healthy and nutritious foods, while $56.7 \%$ and $20.0 \%$ were involved in the building of maternity centers and provision of boreholes/pipeborne water, respectively. This is in agreement with the findings of [2] that community members work together in providing infrastructure in their communities. Similarly, authors [6] report that communities provide most of their needs through self-help efforts which include the provision of markets, water, maintenance of roads that link settlements. The low involvement in borehole drilling could be due to the high capitalintensive nature of the project. Some drilling could take up to 2 million before it can be put to use. 
Table 2 - Involvements in rural community development

\begin{tabular}{|l|c|}
\hline \multicolumn{1}{|c|}{ Areas of involvement } & $\begin{array}{c}\text { Percentage } \\
\text { (n=60) }\end{array}$ \\
\hline Educational projects & 55.9 \\
\hline Building of primary schools & 61.7 \\
\hline Building of secondary schools & 8.3 \\
\hline Award of scholarships to indigenes & 81.7 \\
\hline Establishment of lesson centres & 71.7 \\
\hline Health projects & 58.7 \\
\hline Building of maternity centres & 56.7 \\
\hline $\begin{array}{l}\text { Provision of bore holes/pipe } \\
\text { borne water }\end{array}$ & 20.0 \\
\hline Building of cottage hospitals & 81.7 \\
\hline $\begin{array}{l}\text { Provision of nutritious and healthy } \\
\text { foods }\end{array}$ & 65.0 \\
\hline $\begin{array}{l}\text { Provision of midwifery skill } \\
\text { acquisition centres }\end{array}$ & 70.0 \\
\hline Social projects & 62.1 \\
\hline Building of houses for widows & 56.7 \\
\hline Formation of women association & 91.7 \\
\hline Building of churches & 41.7 \\
\hline Building of town halls & 58.3 \\
\hline Agricultural projects & 85.8 \\
\hline Formation of cooperative societies & 85.0 \\
\hline $\begin{array}{l}\text { Seasonal crop production and } \\
\text { processing }\end{array}$ & 90.0 \\
\hline Household animal and dairy & 88.3 \\
\hline Animal rearing and sales & 96.7 \\
\hline Corn processing outfits & 91.7 \\
\hline Cassava grafting outfits & 60.0 \\
\hline
\end{tabular}

Social RCD projects. Table 2 indicates that women were involved in the provision of social projects in the following areas: formation of women associations $(91.7 \%)$, the building of town halls (58.3\%), the building of houses for the widows $(56.7 \%)$ and building of churches (41.7\%). The result implies that most of the respondents participated more in the formation of women associations which favored them more because of their difficulties in accessing productive resources. The difference in involvement in social projects could be since some of the RCD projects were gender-specific and as a result, women participated more in those projects that favored them most.

Agricultural RCD projects. Table 2 shows that women were involved in the provision of agricultural projects in the following areas: animal rearing and sales (96.7\%), corn processing units (91.7\%), seasonal crop production and processing $(90.0 \%)$, household animal and dairy (88.3\%), formation of cooperative societies $(85.0 \%)$ and cassava grafting outfits $(60.0 \%)$.
This result implies that women were actively and heavily involved in agricultural activities, especially animal production and marketing. This is in agreement with [19] who confirmed that women have been known to take an active part in agriculture compare to men. The authors reported that women provide an estimated percentage of $60-80 \%$ of labor in agriculture, especially in livestock rearing, food production, processing, marketing among other agricultural activities.

Involvement in Rural Community Development groups. Table 3 shows that the respondents were highly involved in market women group $(\overline{\boldsymbol{x}}=2.45)$, traders association $(\overline{\boldsymbol{x}}=2.45)$ and Esusu group ( $\bar{x}=2.02)$. This could be because the majority of the respondents were traders who likely do their businesses in the market square, and as such have a high probability of joining traders and market women association. These associations are often cherished by most women, such that any woman who is not part is not considered serious. Market women association especially is a voice through which women obtain their rights and privileges. They command so much power, so much so that governments listen to them. High involvement in Esusu group could be associated with the fact that most business owners bank on it to build their capital. And considering the difficulties women face in raising capital for business, many of them are most times pushed to join the group for capital security. This is so because, with the meagre amount, one can access quite a lump sum of money to start or boost a business, which in turn can be paid back gradually.

Table 3 - Involvement in rural community development groups

\begin{tabular}{|l|c|}
\hline \multicolumn{1}{|c|}{ Rural community groups } & Mean $(\overline{\boldsymbol{x}})$ \\
\hline Youth association & 1.87 \\
\hline August meeting women group & 1.28 \\
\hline Market women group & $2.45^{*}$ \\
\hline Traders' association & $2.45^{*}$ \\
\hline Cooperative society & 0.82 \\
\hline Daughters' association (Umuada) & 0.32 \\
\hline Political group & 0.07 \\
\hline Religious group & 0.15 \\
\hline Esusu group & $2.02^{*}$ \\
\hline
\end{tabular}

Notes: Bench mark mean $=2.0$

The poor involvement in political groups $(\bar{x}=0.07)$ could be associated with the disingenuousness attribute of most political groups in Nigeria. Many political platforms don't keep to 
their words; promising much but deliver little or nothing. It is always the game of survival of the cleverest, which negates the unity and peaceloving features of womanhood.

Factors enabling women involvement in RCD Projects. The enabling factors for the respondents' participation in RCD projects as shown in Table 4 included: education $(\bar{x}=2.42)$, urbanization $(\bar{x}=2.42)$, migration $(\bar{x}=2.40)$, globalization $(\bar{x}=2.05)$, lack of basic amenities from government $(\bar{x}=1.78)$ and philanthropic reasons $(\bar{x}=1.73)$.

Table 4 - Factors enabling involvement in rural community development projects

\begin{tabular}{|l|c|c|}
\hline \multicolumn{1}{|c|}{ Enabling factors } & $\begin{array}{c}\text { Mean } \\
(\overline{\boldsymbol{x}})\end{array}$ & $\begin{array}{c}\text { Std. } \\
\text { deviation }\end{array}$ \\
\hline Education & $2.42^{*}$ & 0.59 \\
\hline Urbanization & $2.42^{*}$ & 0.73 \\
\hline Globalization & $2.05^{*}$ & 0.63 \\
\hline Migration & $2.40^{*}$ & 0.87 \\
\hline Philanthropic reasons & $1.73^{*}$ & 0.95 \\
\hline $\begin{array}{l}\text { Lack of basic amenities from } \\
\text { government }\end{array}$ & $1.78^{*}$ & 0.84 \\
\hline $\begin{array}{l}\text { Membership to development } \\
\text { projects }\end{array}$ & 0.98 & 0.92 \\
\hline
\end{tabular}

Notes: Bench mark mean=1.5

Education is mind and opportunity opener; it makes for acceptance of new ideas. When women are provided with equal rights and access to education, they could participate in business and economic activity with rural development is a view. Educating women is fundamental to the economic and social development of a nation [10, 8]. This agrees with [17] who affirms that education creates a favourable mental attitude for acceptance of new ideas and practices. Similarly, [19] show that education is one of the important factors that help developers to be realized.

Urbanization is development. Getting urbanization and rural development right is essentially about sharing prosperity. It is about ensuring that the benefits of development and growth reach all citizens [9] - whether men or women.
The quest for urbanization could engineer women's involvement in RCD.

Migration avails one the opportunity to see what is obtainable in other places, and such could drive a person to replicate similar things. People are challenged most times to dare their fears when they move out. Globalization is another trigger for development. Access to global information on developmental projects undertaken by women could spur one into doing the same. On many occasions, people remain in their cocoon because of a lack of information, but with an increasing level of access to what is happening in other places such a barrier is being broken. This is in agreement with the Centre for Technology which stated that technology has transformed human lifestyle and development more rapidly in the last 10 years than ever before. It also added that the world is now like a global village which by implication is a small space in which people live, one where they know everything about everyone and everything that happens.

Lack is another factor that propels people into action. This agrees with [3] who said that no government, no matter how abundantly blessed with economic resources, can hope to single-handedly tackle the problem of rural under-development. The limitation in resources and neglect of most rural communities by the government could push women into undertaking basic social developmental projects.

Women are generally known as caregivers either at home or in society. They are often ready to give back to society. Women mostly think of contribution. This could explain why they are multifarious; always doing many income-generating activities to meet up with demands.

\section{CONCLUSIONS AND RECOMMENDATIONS}

Women were involved in RCD. And they were enabled mainly by exposure to education, urbanization, migration, and globalization. Government and non-governmental agencies should pay more attention to RCD enabling factors such as education, urbanization, migration, globalization among others so that they can find more expression among women. 


\section{REFERENCES}

1. Agada, M. O. (2011). Socio-economic and Cultural Analysis of Food Security among Selected Ethnic Groups in North Central Nigeria. Retrieved from https://iproject.com.ng/agriculture/socioeconomic-and-cultural-analysis-of-food-security-among-selected-ethnic-groups-in-northcentral-nigeria/index.html

2. Apesughur, D. A., Ashiki, G. M., Kim, I., \& Yusuf, K. (2014). Assessment of self-help initiatives and the development of rural communities in Agatu local government area of Benue State, Nigeria. Global Journal of Agricultural Economics, Extension and Rural Development, 2(5), 152-160.

3. Apu,U., Ekumankama, O. 0., \& Unamma, R. P. A. (2012). Assessment of rural peoples' participation in providing safe water supply scheme in Abia State, Nigeria. International Journal of Applied Research and Technology, 1(6), 57-62.

4. Dethier, J.-J., \& Effenberger, A. (2012). Agriculture and development: A brief review of the literature. Economic Systems, 36(2), 175-205. doi: 10.1016/j.ecosys.2011.09.003

5. Egbe, E. J. (2014). Rural and community development in Nigeria: an assessment. Arabian Journal of Business and Management Review (Nigerian Chapter), 2(2), 17-30.

6. Ehisuoria, S. E., \& Akhimien, F. O. (2012). An assessment of community self-help efforts in the development of Emuhi community in South-South region Nigeria. Retrieved from https://www.semanticscholar.org/paper/An-Assessment-of-Community-Self-Help-Efforts-inthe-Ehisuoria-Akhimien/8ae7866d0a66bfcae4448c13ac71543ca133761e\#paper-header

7. Haruna, M. J., \& Liman, B. M. (2015). Challenges facing educating Nigerian child in rural areas: implications for national development. Retrieved from https://pdfs.semanticscholar.org/84f1/f8bb2275ffaed90d57434276f0d4fa190c77.pdf?_ga=2.1 74760162.1983668023.1582973234-1042230176.1581878685

8. IndiaCelebrating.com (2017). Importance of Education for Women. Retrieved from https://www.indiacelebrating.com/article/importance-of-education-for-women

9. Indrawati, S. M. (2014, March 23). Urbanization and Urban-Rural Integrated Development. Retrieved from https://www.worldbank.org/en/news/speech/2014/03/23/urbanization-and-urbanrural-integrated-development

10. Mystory. (2019). Why is Education Important for Women? Retrieved from https://yourstory.com/mystory/why-is-education-important-for-women-fiqb8hi1ie

11. Nwachukwu, I. (2013). Agricultural Extension and Rural Development Promoting Indigenous Knowledge (2nd ed.). Umuahia: Lamb House Publications.

12. Ogunleye-Adetona, C. I., \& Oladeinde, C. (2013). The role of community self-help projects in rural development of Kwara State, Nigeria. International Journal of Development and Sustainability, 2(1), 28-45.

13. Ukpongson, M. A., Chikaire, J., Nwakwasi, R. N., Ejiogu-Okereke, N., \& Emeana, E. M. (2014). Problems of Financing Community Development Projects in Obowo Local Government Area of Imo State, Nigeria. Academia Arena, 6(9), 80-86.

14. United Nations. (2018). World Urbanization Prospects 2018. Retrieved from https://population.un.org/wup/

15. Usharani, R. \& Mamudu A.N. (2014). Self-Help Groups as a livelihood development for rural women: Experiences from India and Ghana. Journal of Economics and Sustainable Development, 5(15), 194-200.

16. Utuk, I. O. (2014). The role of non-governmental organizations (NGOs) in participatory and sustainable rural economic development in Nigeria. Journal of Economics and Finance, 4(1), 2230 . 
17. World Development Bank. (2011). Second National Fadama Development Critical Ecosystem Management Project. Retrieved from https://projects.worldbank.org/en/projectsoperations/project-detail/P073686?lang=en

18. Yamusa, I., \& Adefila, J. O. (2014). Farmers' cooperatives and agricultural development in Kwali Area Council, Federal Capital Territory Abuja, Nigeria. International Journal of Humanities and Social Science, 4(7), 161-169.

19. Yemisi, G. M., \& Idisi, D. P. (2014). Gender inequality and women participation in agriculture development in Nigeria. Merit Research Journals, 2(11), 296-301. 